\title{
AMINO ACID AND VITAMIN CONTENT OF PROPOLIS COLLECTED BY NATIVE CAUCASICAN HONEYBEES
}

\author{
Nazife Eroglu ${ }^{1 *}$ \\ Senem Akkus² \\ Mustafa Yaman² \\ Baris Asci ${ }^{3}$ \\ Sibel Silici ${ }^{4}$ \\ ${ }^{1}$ The Scientific and Technological Research Council of Turkey \\ 2 The Scientific and Technological Research Council of Turkey, Marmara Research \\ Center Food Institute \\ ${ }^{3}$ Ardahan University, School of Health Science \\ ${ }^{4}$ Erciyes University, Faculty of Agricultural Biotechnology \\ * corresponding author email: nazifeeroglu@hotmail.com \\ Received: 8 March 2016; accepted: 19 August 2016
}

A bstract

The polyphenol content of propolis has received a lot of attention due to the benign biological properties noted in the chemical composition studies. However, there are very limited studies about other chemical components found in trace amounts in nature which contribute to the therapeutic properties of propolis. The present study, therefore, investigated the amino acid and vitamin composition of propolis. Propolis harvested by 60 colonies of Apis mellifera caucasica belonged to local non-migratory beekeepers. The $A$. $m$. caucasica is known for its distinctive propolis collecting capability which native to the secluded Ardahan Province of Turkey. Vitamin (Thiamine, Riboflavin) combinations of propolis were determined using the HPLC (High-Performance Liquid Chromatography) fluorescent detector. An amino acid analysis was also performed with the UFLC (Ultra-Fast Liquid Chromatography) system consisting of binary pump and UVIVIS. Our findings record that the vitamin and amino acid content of propolis samples collected from three areas of different altitudes in the same region differed from each other. Vitamin B1 content and Vitamin B2 content ranged between $0.025-0.16 \mathrm{mg} / 100 \mathrm{~g}$, and $0.304-0.777 \mathrm{mg} / 100 \mathrm{~g}$, respectively. A maximum amount of amino acid was reported as leucine, while a minimum amount of amino acid was seen as tryptophan in Ardahan propolis. Consequently, the vitamin and amino acid content of propolis, which derived from secondary plant metabolites of resin, varied depending on their geographical altitudes. Those vitamin and amino acids found in the propolis composition are believed to have beneficial therapeutic properties.

Keywords: amino acids, B group vitamins, caucasican honeybees, propolis

\section{INTRODUCTION}

All animals need essential amino acids (EAAs) to develop, reproduce, and for somatic maintenance. These amino acids are required for the purpose of enzyme production, peptide or amine signaling, tissue repair, and basic somatic functions, such as the immune system. Essential amino acids are provided when consuming proteins found in other animals or plants. The need for these compounds decreases over the lifespan of an animal (Millward et al., 1997; Tigreros 2013, van de Rest et al., 2013).
Throughout the larval stage of the honeybee, plants are a source of pollen and nectar-provided protein, and other essential nutrients (Westrich, 1990). Protein in the honeybee diet is reported to be important for development, reproduction, and longevity (Roulston \& Cane, 2002). Honeybees were reported to prefer plants with a high amino acid content (Alm et al., 1990). The essential amino acids in pollen (arginine $11 \%$, histidine $5 \%$, isoleucine $14 \%$, leucine $16 \%$, lysine $11 \%$, methionine $5 \%$, phenylalanine $9 \%$, threonine $11 \%$, tryptophan $4 \%$, and valine $14 \%$ ) were determined for honeybees (De Groot, 
1953). The amino acids found in propolis were assumed to originate from plants with resinous substance as well as saliva resulting from bee metabolism (Marcucci et al., 1996). On the other hands, vitamins are organic compounds needed for providing normal growth and development. Vitamins aid the general wellbeing of animals and insects. Vitamins have different chemical compositions and biological functions, and most importantly are used for numerous metabolic pathways and the synthesis of essential co-factors controlled by enzymes and coenzymes (Ball, 1994). Water-soluble vitamins (Vitamins B1, B2, B6, B12, folic acid, pantothenic acid, niacin, Biotin, and Vitamin C) are involved in the metabolism of fats, carbohydrates, and proteins, at different stages. Water-soluble vitamins are not stored in the body.

Propolis is recorded to have more than 300 compounds. The chemical constituents are changed greatly by environmental conditions, such as region, season, climate, flora, altitude. Honeybees also affect the constituents (Miguel \& Antunes, 2011; Popova et al., 2010; Sforcin, 2007). The compounds identified in propolis resin originate from 3 sources: 1) plant exudate collected by bees, 2) secreted substances from bee metabolism, 3) and materials which are introduced during propolis elaboration (Ghisalberti, 1979; Marcucci et al., 1994). The chemical composition of propolis is identified as $50 \%$ resin and vegetable balsam (composed of flavonoids and related phenolic acids called the polyphenolic fraction), $30 \%$ waxes, $10 \%$ essential and aromatic oils, 5\% pollen, and other organic compounds (Burdock, 1998; Popova et al., 2010). The "other organic compounds" also make up the rest of $5 \%$. These other compounds contain proteins, amino acids, amines and amides of total $0.7 \%$ of all and trace amounts of carbohydrates, lactones, quinones, steroids, and vitamins. In early studies, vitamins $B 1, B 2, B 6, C, E$, and mineral elements of silver, cesium, mercury, lanthanum, antimony, copper, manganese, iron, calcium, aluminum, vanadium, and silicon have all been identified in propolis samples from different botanical and geographical origins (Deblock-Bostyn, 1982; Debuyser,
1983; Dogan et al., 2006). Yet, there аге very few studies addressing the amino acid contents of propolis (Greenaway et al., 1990; Gabrys et al., 1986; Могеira, 1986).

Our research aimed to determine the vitamin (B1 and B2) and amino acid contents of Ardahan propolis and evaluate the quantity compare with previous studies.

\section{MATERIAL AND METHODS}

\section{Collection of propolis samples}

Sixty samples of Turkish propolis were obtained from three selected apiaries in Ardahan, northeastern Turkey. Ardahan Province is surrounded by high mountains in the northeastern border of Turkey to the Caucasus region of Eurasia. Ardahan Province is a naturally formed, isolated rural area far away from industrialized zones. Traditional non-migratory beekeeping is very common due to the geography and climate. All of the apiaries in this study are owned by stationary local beekeepers that never migrate. Beekeepers' location and geographical zone was determined by GPS (Magellan). Each apiary which had 20 strong (8-10 bee covered frames) colonies utilized plastic propolis traps on the top of the hive during the experiment. Samples were hand-collected between August-October 2014 , and kept at a deep freeze $\left(-25^{\circ} \mathrm{C}\right)$, and protected from light. The Ardahan region had a total of $3 \times 20=60$ colonies. Propolis samples for the extraction were randomly chosen in three locations to represent the Ardahan area. Sample collecting locations were recorded as Ardahan-Center in the village of Kartalpinar [(38T) 0310696 E 4558178 N], Ardahan-Center in the village of Sugoze [(38T) $0303427 \mathrm{E}$ $4552596 \mathrm{~N}]$, and Ardahan-Posof in the village of Kumlukoz [(38T) 0315551 E 4604278 N]. To make a uniform sampling, 10 grams of raw propolis were used from each beehive and were distributed accordingly for the analyses. The altitude of each location was recorded for the highest zone of Kartalpinar (1835 m), Sugoze (1746 m), and Kumlukoz (1431 m). 


\section{Identification of honeybee samples}

Caucasican honeybees were identified by Duzce University, Department of Biology using classic morphometric techniques which considered the right forewing venation and angles.

\section{Chemicals}

In this study, most of the analytes were obtained from Sigma (Sigma-Aldrich $\mathrm{GmbH}$, Sternheim, Germany) except HPLC grade methanol which was purchased from Merck (Darmstadt, Germany).

\section{Analysis of vitamins}

\section{Tiamin (Vitamin B1) analyses}

$1 \mathrm{~g}$ of homogenized propolis sample was inserted in a $100 \mathrm{ml}$ flask containing $60 \mathrm{ml}$ of $0.1 \mathrm{~N}$ $\mathrm{HCl}$ and the solution was autoclaved at $121^{\circ} \mathrm{C}$ for $30 \mathrm{~min}$. After cooling down to $37^{\circ} \mathrm{C}$ or room temperature, it was $\mathrm{pH}$ adjusted to 4.5 with sodium acetate solution and the following was added: taka-diastase, clara-diastase, papain, alpha-amylase, and acid phosphatase enzyme. After shaking in a water bath at $45^{\circ} \mathrm{C}$ for 3 hours, the sample cooled to room temperature and the volume was completed to $100 \mathrm{ml}$ with a $0.1 \mathrm{~N}$ hydrochloric acid solution. Then the solution was filtered through ordinary filter paper and centrifuged at $4500 \mathrm{rpm}$ for $5 \mathrm{~min}$. Twenty-five $\mathrm{ml}$ of solution was placed into a polyethylene tube, and after that $1.5 \mathrm{ml}$ potassium ferricyanide $(1 \% \mathrm{w} / \mathrm{v})$ solution was added, and then the $\mathrm{pH}$ was adjusted to 7.0 with an ortho-phosphoric acid solution. The mobile phase included $1000 \mathrm{ml}$ of phosphate buffer and $250 \mathrm{ml}$ of methanol mix and an adjustment to a $\mathrm{pH}$ of 7. The detector was FLD (Fluorescence detector). The wavelength covered excitation of $366 \mathrm{~nm}$ and emission of $445 \mathrm{~nm}$. High-performance liquid chromatography (HPLC) column

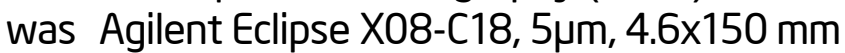
with a flow rate of $1 \mathrm{ml} / \mathrm{min}$ (AOAC, 2011; Eitenmiller et al., 2008; Esteve et al., 2001; Finglas et al., 1984).

\section{Riboflavin (Vitamin B2) analyses}

$\mathrm{g}$ of propolis was placed in a $100 \mathrm{ml}$ flask containing $60 \mathrm{ml}$ of $0.1 \mathrm{~N} \mathrm{HCl}$, and the solution was autoclaved at $121^{\circ} \mathrm{C}$ for 30 min. After cooling down to $37^{\circ} \mathrm{C}$, the $\mathrm{pH}$ was adjusted to 4.5 with a sodium acetate solution, and after that mixture of acid phosphatase and taka-diastase enzyme solution was added. After shaking in a water bath at $45^{\circ} \mathrm{C}$ for 3 hours, the solution was boiled for 10 minutes. The cooled sample solution was brought to 100 $\mathrm{ml}$ with $0.1 \mathrm{~N} \mathrm{HCl}$ and centrifuged at $4500 \mathrm{rpm}$ for $5 \mathrm{~min}$. The final solution was filtered through ordinary filter paper and passed through a 0.45 $\mathrm{m}$ filter and injected onto the HPLC. The mobile phase differed from the Tiamin extraction and included $1000 \mathrm{ml}$ of phosphate buffer and 250 $\mathrm{ml}$ of methanol mix and an adjustment to a $\mathrm{pH}$ of 2.5. The detector was a FLD (Fluorescence detector). The wavelength covered excitation of $445 \mathrm{~nm}$ and emission of $525 \mathrm{~nm}$. The high-performance liquid chromatography column was Agilent Eclipse X08-C18, 5 $\mu \mathrm{m}, 4.6 \times 150 \mathrm{~mm}$ with a flow rate of $1 \mathrm{ml} / \mathrm{min}$ (AOAC, 2011; Eitenmiller et al., 2008; Esteve et al., 2001; Finglas et al., 1984). All vitamin analyses were run twice.

\section{Amino acid analyses}

The analysis method included 17 amino acids (aspartic acid, glutamic acid, serine, glycine, arginine, histidine, threonine, lysine, alanine, proline, leucine, isoleucine, tyrosine, phenyl alanine, valin, methionine, and tryptophan). The procedure firstly requires the alkaline hydrolysis of protein for tryptophan and an acid hydrolysis for others in sealed glass bottles under $\mathrm{N}_{2}$ atmosphere. Following the protein hydrolysis, the method involved filtration, extraction with a mixture of acetonitril, methanol and triethylamine, pre-column derivatisation and detection of 16 amino acids (Asp, Glu, Ser, Gly, Arg, His, Thr, Lys, Ala, Pro, Leu, lle, Tyr, Phe, Val, and Met). The solution being used for derivatisation included Edman reagent. After derivatisation, separation was done on reverse-phase analytical columns and detection and analyses was done with the UFLC (Ultra fast liquid chromatography) system which consisted of a binary pump and UVIVIS detector.

Following hydrolysis, the hydrolysates were 
filtered and the $\mathrm{pH}$ values were adjusted with $\mathrm{HCl}$ solution. Separation and detection occurred on a reversed-phase analytical column of HPLC using a fluorescence detector within 10 minutes (Gheslaghi et al., 2008; Dimova 2003). Amino acid analyses were done by double run for a single propolis sample. Each sample was also injected twice so that a single colony was represented four times.

\section{RESULTS}

The qualitative and quantitative analyses of the propolis samples gathered from selected villages of three different altitudes were determined. A highest content of amino acid in these samples was found in the village of Sugoze, followed by the villages of Kartalpinar and Kumlukoz. The entire 17 amino acids were present in all of the studied samples, however, individual amounts of amino acids varied depending on the location
(Tab. 1). Leucine was the most abundant amino acid found at the Sugoze location. In this location, more than $300 \mathrm{mg} / \mathrm{kg}$ leucine and proline, accompanying more than $200 \mathrm{mg} /$ $\mathrm{kg}$ alanine and valine amino acids, $100 \mathrm{mg} / \mathrm{kg}$ of aspartic and glutamic acids, serine, glycine, threonine, isoleucine, phenylalanine, and lysine, were detected. Other amino acids which made up less than $100 \mathrm{mg} / \mathrm{kg}$ were also detected. The propolis samples obtained from the village of Kartalpinar displayed over $100 \mathrm{mg} / \mathrm{kg}$ of leucine, proline, alanine, threonine, valine, lysine, glycine, and aspartic acids, and less amounts of other amino acids. In Kumlukoz, leucine surprisingly, was the only amino acid found above $100 \mathrm{mg} / \mathrm{kg}$ from among all the amino acids; all other amino acids were detected below this value. The only difference among propolis samples produced by the same honeybee (A.m. caucasica L.) subspecies from the same isolated region, was the altitude. Consequently, from the amino acids, leucine had the highest rate determined

Table 1

Amino acid composition of propolis samples from Ardahan, northeast Anatolia, collected by Caucasican honeybees (Apis mellifera caucasica)

\begin{tabular}{cccc}
\hline Amino acids & $\begin{array}{c}\text { Ardahan-Center- } \\
\text { Sugoze } \\
(\mathrm{mg} / 100 \mathrm{gr})\end{array}$ & $\begin{array}{c}\text { Ardahan-Center-Kartal- } \\
\text { pinar }(\mathrm{mg} / 100 \mathrm{gr})\end{array}$ & $\begin{array}{c}\text { Ardahan-Posof-Kum- } \\
\text { lukoz (mg/100gr) }\end{array}$ \\
\hline Mspartic acid & $135.6 \pm 0.4$ & Mean \pm SD & Mean \pm SD \\
\hline Glutamic acid & $140.4 \pm 5.1$ & $103.9 \pm 0.9$ & $71.2 \pm 2.2$ \\
Serine & $162.6 \pm 1.1$ & $94.9 \pm 1.4$ & $57.0 \pm 0.7$ \\
Glycine & $190.2 \pm 0.8$ & $83.5 \pm 1.2$ & $60.7 \pm 0.4$ \\
Histidine & $57.8 \pm 1.1$ & $104.4 \pm 1.2$ & $75.2 \pm 0.1$ \\
Arginine & $76.0 \pm 0.0$ & $47.8 \pm 3.1$ & $37.9 \pm 0.6$ \\
Threonine & $198.0 \pm 0.9$ & $52.8 \pm 0.9$ & $37.1 \pm 0.2$ \\
Alanine & $291.2 \pm 5.1$ & $118.5 \pm 0.4$ & $70.4 \pm 0.6$ \\
Proline & $301.0 \pm 6.6$ & $132.3 \pm 4.6$ & $74.6 \pm 2.2$ \\
Tyrosine & $99.4 \pm 0.4$ & $154.9 \pm 3.6$ & $81.0 \pm 2.6$ \\
Valine & $229.5 \pm 1.1$ & $63.8 \pm 1.5$ & $45.9 \pm 0.2$ \\
Methionine & $55.5 \pm 3.7$ & $116.1 \pm 0.4$ & $82.4 \pm 0.3$ \\
Isoleucine & $172.8 \pm 0.9$ & $30.9 \pm 0.7$ & $28.3 \pm 0.1$ \\
Leucine & $332.0 \pm 1.1$ & $94.3 \pm 0.2$ & $58.7 \pm 0.0$ \\
Phenylalanine & $160.4 \pm 0.5$ & $163.2 \pm 1.2$ & $115.5 \pm 0.2$ \\
Lysine & $126.5 \pm 1.2$ & $89.5 \pm 0.4$ & $55.5 \pm 0.2$ \\
Tryptophan & $35.5 \pm 0.9$ & $111.8 \pm 0.9$ & $71.7 \pm 0.4$ \\
Total & 2764.5 & $33.9 \pm 0.1$ & $24.9 \pm 0.5$ \\
\hline
\end{tabular}


in all propolis samples, followed by proline and alanine. The B1 and the B2 vitamin content of the propolis samples ranged from 0.16 to 0.39 $\mathrm{mg} / 100 \mathrm{~g}$, and from 0.304 to $0.777 \mathrm{mg} / 100 \mathrm{~g}$, respectively (Tab. 2). While the highest vitamin B1 content was found in the Kumlukoz samples. The village of Sugoze was recorded with the most vitamin $\mathrm{B} 2$ content. of the many pollen species were determined even though the amino acids were in relatively small quantities (Micheu et al., 2000). However, there was as absence of tryptophan in some pollen types reported in some studies (Auclair \& Jamieson, 1948; Roulston \& Cane, 2000), while other studies reported trace amounts of tryptophan (Weiner, 2010). In another study, a

Table 2

Vitamin structure based on Vitamin B1, and B2, of propolis samples from Ardahan, northeast Anatolia collected by Caucasican honeybees (Apis mellifera caucasica).

\begin{tabular}{ccc}
\hline Region & $\begin{array}{c}\text { Vitamin B1 } \\
(\mathrm{mg} / 100 \mathrm{~g})\end{array}$ & $\begin{array}{c}\text { Vitamin B2 } \\
(\mathrm{mg} / 100 \mathrm{~g})\end{array}$ \\
\hline Ardahan-Posof-Kumlukoz & 0.16 & 0.426 \\
Ardahan-Center-Sugöze & 0.16 & 0.437 \\
Ardahan-Center-Kartalpınar & 0.025 & 0.746 \\
& 0.027 & 0.777 \\
\hline
\end{tabular}

*Standard deviation of vitamin samples 0.1568

\section{DISCUSSION}

Throughout their larval stage, honeybees are fed primarily by pollen and nectar gathered from the plants. Pollen and nectar are the main source of protein and other essential nutrients (Westrich, 1990). Protein and vitamins found in their diet are crucial for the development, reproduction, and lifespan of honeybees (Roulston \& Cane, 2002). Studies done on honeybee diets reported the importance of the diets, and that 10 amino acids are needed for honeybee development. The 10 needed amino acids are arginine, histidine, Iysine, tryptophane, phenylalanine, methionine, threonine, leucine, isoleucine, and valine (De Groot, 1953). It is well known that the vital functions of honeybees depend on protein and vitamin content received from pollen. The full spectrums of essential amino acids in some comparison was done of Taraxacum officinale pollens compiled by the honey bees versus hand-picked pollens, Proline and valine were found the most in the the hand-collected pollen (Loper \& Coohen, 1987). The quantitative differences in pollen protein lead to differences in the growth stimulation of the hypopharyngeal glands of worker bees. The proteins that contain a suitable amount and variety of amino acids are needed for normal growth and development of honeybees. It is clear that plant pollens do not have the same essential amino acids both qualitatively and quantitatively. Therefore, honeybees chose to collect pollen from a variety of plants instead of certain plant species and prefer some pollen less than other pollen. Honeybee preference of pollen collection is significant to provide enough nutrition for the growth and development of bees from different plant sources (Cook et al., 2003). 
Propolis is not the primary source of amino acids and vitamins for honeybees. Recent studies reported that propolis is often contaminated with a small amount of pollen and plant leaf fragments (Zarakomska \& Maciejewicz,1992). The differences in the amino acid composition in the propolis samples were attributed by Marcucci (1996) to the variation of plant resources. He identified 11 amino acids. But, aspartic acid, glutamic acid, threonine, proline, valine, tyrosine, and histidine may be present in all samples. There were no differences in the percentage of the alanine, aspartic, glutamic acids, glycine, and histidine, despite the different botanical origins. These amino acid were recorded to emanate from the pollen sources (Marcucci, 1996). It was noted by Gabrys et al. (1986) that total propolis acid extraction contains more than $40 \%$ (w/w) amino acid concentration determined by gas-liquid chromatography (GC), whereas arginine and proline were found to be above $50 \%$ of the crude acid extract. Additionally, proline amino acid which is one of the compounds of propolis, was reported to contribute to this activity by promoting the production of collagen and elastin. In another study, propolis was reported to contain B1, B2, B6, C, and Vitamin E, with some enzymes like succinic dehydrogenase, glucose- 6-phosphatase, adenosine triphosphatas, and acid phosphatase (Tikhonov \& Mamontov, 1987). It was reported by Sorkun et al. (2001) that there was more amino acid content in the propolis collected from Erzurum in the East Anatolia than that collected from the Trabzon and Gumushane regions in the Black Sea area, Turkey. Since, there are inadequate references to compare our findings on the vitamin content of propolis, there is very little to say to interpret the results. However, Vitamin B1 and B2 in our propolis samples are believed to originate from pollen sources.

De Groot (1953) reported that methionine, arginine, tryptophan, lysine, isoleucine, phenylalanine, histidine, valine, leucine, and threonine were essential amino acids for honey bees, while tyrosine, cysteine, serine, hydroxyproline, alanine, glycine, and proline were nones- sential. In addition, of the essential amino acids, leucine, isoleucine, and valine were required in the greatest amounts (as the most essential amino acids), tryptophan, methionine, and histidine in the lowest amounts (as the least essential amino acids), while threonine, phenylalanine, arginine, and lysine were required in amounts in-between these.

The nutritional needs of honeybees in a colony vary according to age and performed tasks. Adult worker bees, for instance, give more of a priority to carbohydrates in their diets than to EAA. For younger bees, the nutritional needs, especially of EAA, are greater. These needs may change by age and also by being a forager (Paoli et al., 2014). Hence, a preference for different types of pollen in the honeybee diet is inevitable (Standifer et al., 1977). At this point, even though it is considered as contaminating propolis, the amino acid composition may provide us with knowledge about the nutrients needed by the honeybee at different stages of their life. Marcucci (1996) evaluated both leaf fragments of dicotyledonous plants and resins of propolis to determine the amino acid structure. His examination revealed important differences of methionine, phenylalanine, and tyrosine. It was reported that these amino acids either were associated or involved bee metabolisms. Indeed, the three sources of amino acid content of propolis were cited as plants, pollen contamination, and bee metabolisms (Marcucci et al., 1996).

In our study, leucine showed the highest abundance rates compared to the other amino acids in the analysed samples. The function of leucine is important to build muscle structure, which is needed the most by honeybees. Due to the excessive flight and muscle activities during propolis collecting time (scraping, making pellets, loading and unloading), it is believed that this amino acid is much-needed. A preference for leucine-rich pollen sources may involve propolis production. In addition, it is accepted by many researchers that the vitamin and amino acid content of propolis has therapeutic properties. 


\section{J. APIC. SOLI. YOL. 60 NO. 2.2016}

\section{ACKNOWLEDGEMENTS}

This study was fully supported by The Scientific and Technological Research Council of Turkey (TÜBITAK), BIDEB-2232 Project No: 113C036, Institution Code: 5134103 under the name of "The investigation of the important honeybee, Apis mellifera L. (Hymenoptera, Apidae), subspecies, and ecotypes in Turkey in regards to the propolis collection capacity and chemical characterization of Turkish propolis". The authors gratefully acknowledge Meral Kekecoglu, Duzce University, Department of Biology, Turkey, for the morphological identification of the honeybees.

\section{REFERENCES}

Alm, J., Ohnmeiss, T.E., Lanza, J., Vrisenga, L. (1990). Preference of cabbage white butterflies and honey bees for nectar that contains amino acids. Oecologia, 84, 53-57. Dol:10.1007/BF00665594

AOAC-International Official Methods of Analysis, 18th ed. (2011). Current through Revision 2, 2011 (On-line), AOAC International, Gaithersburg, MD. Retrieved December 1, 2015, from http://www.eoma. aoac.org/

Auclair, J.L., \& Jamieson, C.A. (1948). A qualitative analysis of amino acids in pollen collected by bees. Science, 108(2805), 357-358. DOl: 10.1126/science.108.2805.357

Ball, G.F.M. (2006). Vitamins in Foods, Analysis, Bioavailability, and Stability. CRC Taylor and Francis: Florida.

Burdock, G.A. (1998). Review of the biological properties and toxicity of bee propolis (propolis). Food and Chemical Toxicology, 36(4), 347-363. http:/l dx.doi.org/10.1016/S0278-6915(97)00145-2

Cook, S.M., Awmack, C.S., Murray, D.A., Williams, I.H. (2003). Are honey bees' foraging preference affected by pollen amino acid composition? Ecological Entomology, 28, 622-627. DOl: 10.1046/j.13652311.2003.00548.x

Debuyser, E. (1983). La propolis. Docteur en Pharma- cie Thesis, Universite de Nantes, France 82 pp.

Deblock-Bostyn, G. (1982). L'Abeille et ses produits. Bulletin de la Société de pharmacie de Bordeaux. Lille 38, 181-203.

De Groot, A.P. (1953). Protein and amino acids requirements of the honeybee (Apis mellifera). Physiologia Comparata et d'Eclogia, 3, 197-285.

Dimova, N. (2003). RP-HPLC Analysis of Amino acids with UV-Detection, Bulgarian Academy of Science, Tome 56, No 12. Bibliographic Code: 2003CRABS..56l..75D

Dogan, M., Silici, S., Saraymen, R., IIthan, I.O. (2006). Element content of propolis from different regions of Turkey. Acta Alimentaria, 5(1), 127-130. DOl: 10.1556/AAlim.35.2006.1.14

Eittenmiller, R.R., Lin Ye W.O., \& Landen Jr. (2008). Vitamin Analysis for Food the Health and Food Sciences. CRC Press: New York, Second Edition.

Esteve, M.I., Farre, R., Frigola, A., Cantabella, J.M.G. (2001). Simultaneous Determination of Thiamine and Riboflavin in Mushrooms by Liquid Chromatography. Journal of Agricultural and Food Chemistry, 49, 1450-1454. DOl: 10.1021/jf001040p

Finglas, P.M., \& Faulks, R.M. (1984). The HPLC Analysis of Thiamine and Riboflavin in Potatoes. Food Chemistry, 15, 37-44. http://dx.doi.org/10.1016/03088146(84)90037-2

Gabrys,.J., Konecki,.., Krol, W., Scheller, S., Shani,J.(1986). Free amino acids in bee hive product (propolis) as identified and quantified by gas-liquid chromatography. Pharmacological Research Communications, 18(6), 513-518. http://dx.doi.org/10.1016/00316989(86)90146-3

Gheshlaghi, R., Scharer, J.M., Moo-Young, M., Douglas, P.L. (2008). Application of Statistical Design for the Optimization of Amino Acids Separation by ReversePhase HPLC. Analytical Biochemistry, 383, 93-102. http.//dx.doi.org/10.1016/j.ab.2008.07.032 
Ghisalberti, E.L. (1979). Propolis: a review. Bee World, 60, 59-84.

Greenaway, W., Scaysbrook, T., \& Whatley, F.R. (1990). The composition and plant origins of propolis: a report of work at Oxford. Bee World, 71, 107-118. http:// dx.doi.org/10.1080/0005772X.1990.11099047

Loper, G.M., \& Cohen, A.C. (1987). Amino acid content of dandelion pollen: a honey bee (Hymenoptera: Apidae) nutritional evaluation. Journal of Economic Entomology, 80, 14-17. http://dx.doi.org/10.1093/ jee/80.1.14

Marcucci, M. (1994). Propolis: chemical composition, biological properties and therapeutic activity. Apidologie, 26(2), 83-99. HAL Id: hal-00891249

Marcucci, M.C., Camargo, F.A., \& Lopes, C.M. (1996). Identification of amino acids in Brazilian propolis. Zeitschrift fuer Naturforschung, 57c, 11-14. http:/l dx.doi.org/10.1515/znc-1996-1-204

Micheu, S., Cralsehim, K., \& Leonhard, B. (2000). Importance of proline and other amino acids during honeybee flight (Apis mellifera carnica Pollmann). Amino acids, 18, 157-175. D01:10.1007/s007260050014

Miguel, M.C., \& Antunes, M.D. (2011). Is propolis safe as an alternative medicine? Journal of Pharmacy \& Bioallied Science, 3(4), 479-95. DOI: 10.4103/09757406.90101

Millward, D.J., Fereday, A., Gibson, N., Pacy, P.J. (1997). Aging, protein requirements and protein turnover. American Journal of Clinical Nutrition, 66(4), 774786.

Moreira, T.F. (1986). Chemical composition of propolis: vitamins and amino acids. Revista Brasileira de Farmacognosia, 1, 12-19. http://dx.doi.org/10.1590/ S0102-695X1986000100003

Paoli, P.P., Donley, D., Stabler, D., Saseendranath, A., Nicolson, S.W. (2014). Nutritional balance of essential amino acids and carbohydrates of the adult worker honeybee depends on age. Amino acids, 46, 144914458. DOl:10.1007/s00726-014-1706-2
Popova, M.P., Graikou, K., Chinou, l., Bankova, V.S. (2010). GC-MS profiling of diterpene compounds in Mediterranean propolis from Greece. Journal of Agricultural Food Chemistry, 10(5), 3167-3176. DOl: $10.1021 / j 9903841 \mathrm{k}$

Roulston, T.H., \& Cane, J.H. (2000). Pollen nutritional content and digestibility for animals. Plant Systematics and Evolution, 222, 187-209. D01:10.1007/ BF00984102

Roulston, T.H., \& Cane, J.H. (2002). The effect of pollen protein concentration on body size in the sweat bee Lasioglossum zephyrum (Hymenoptera: Apiformes). Evolutionary Ecology, 16, 49-65. DOl:10.1023/A:1016048526475

Sforcin, J.M. (2007). Propolis and Immune system: a review. Journal of Ethnopharmacology, 15(113), 1-14. http://dx.doi.org/10.1016/j.jep.2007.05.012

Sorkun, K., Suer, B., \& Salih, B. (2001) Determination of chemical composition of Turkish propolis. Zeitschrift fuer Naturforschung, 56, 666-668. DOl: 10.1515/ zחс-2001-7-828

Standifer, L.N., Moeller, F.E., Kauffeld, N.M., Herbert, E.W., Shimanuki, H. (1977). Supplemental feeding of honeybee colonies. USDA Agricultural information Bulletin, No: 413,8p.

Tigreros, N. (2013). Linking nutrition and sexual selection across life stages in a model butterfly system. Functional Ecology, 2 (1), 145-154. DOl: $10.1111 / 1365-2435.12006$

Tikhonov, A.I., \& Mamontova, I.N.S. (1987). Production and study of a lyophilized phenolic preperations from propolis. Farmatsevtichnii Zhurnal, 3, 67-8.

Van de Rest, O., van der Zwaluw, N.L., \& de Groot, L.C.P.G.M. (2013). Literature review on the role of dietary protein and amino acids in cognitive functioning and cognitive decline. Amino Acids, 45(5), 10351045. DOl:10.1007/s00726-013-1583-0

Weiner, C.N., Hilpert, A., Werner, M., Linsenmair, K.E., Blüthgen, N. (2010). Pollen amino acids and flower 
specialisation in solitary bees. Apidologie, 47(4), 476-487. http://dx.doi.org/10.1051/apido/2009083

Westrich, P. (1990). Die Wildbienen Baden-Wrüttembergs II. Eugen Ulmer Verlag, Hohenheim.

Warakomska,Z., \& Maciejewicz, W. (1992). Microscopic analysis of propolis from Polish regions. Apidologie, 23, 277-283. HAL Id: hal-00890993 
